\title{
Domestic Structures, Misalignment, and Defining the Climate Displacement Problem
}

\author{
Susan Sterett 10
}

Citation: Sterett, Susan. 2021.

Domestic Structures, Misalignment, and Defining the Climate

Displacement Problem. Social Sciences 10: 425. https://doi.org/10.3390/ socsci10110425

Academic Editors: Carlos Teixeira, Andrea C. Simonelli and Heather R. Croshaw

Received: 28 June 2021

Accepted: 23 September 2021

Published: 4 November 2021

Publisher's Note: MDPI stays neutral with regard to jurisdictional claims in published maps and institutional affiliations.

School of Public Policy, University of Maryland, Baltimore County, 1000 Hilltop Circle, Baltimore, MD 21250, USA; ssterett@umbc.edu

\begin{abstract}
This paper contrasts how climate reports describe displacement with how analyses of moving after disaster have described whether people move. The paper argues that domestic structures govern displacement, and are likely to continue to. Domestically, people have different legal statuses and access to resources, which shape the ability to move. Authoritative governance documents on climate change, including the United States National Climate Assessment, argue that climate change will lead to increasing numbers of displaced people. On the other hand, demographers and economists who study where people move to after disaster have argued that climate reports overstate the risk of mass displacement, based in what has happened after past disasters. Domestic governance processes influence resettlement, and they can change. Studies of whether people move after disaster do not take into account how changes in insurance rates or other rules shaping where people live could reshape resettlement. On the other hand, analyses of governing potential climate displacement draw on international agreements and documents. has often centered on islands advocates argue will disappear, not the changing habitability of places that also depends on the resources people have. The image of disappearing islands misdirects from the risks of climate displacement in wealthier countries, where some people have extensive resources and others do not. This paper argues that the risk of displacement requires turning to follow the domestic governance processes that shape people's decisions now. This approach fits with calls to work from people's claims up to governance processes, rather than from processes downward.
\end{abstract}

Keywords: climate displacement; lawsuits; claims-making; disaster

\section{Introduction: Integrating Decisions with Ordinary Domestic Law ${ }^{1}$}

In spring 2021, my immediate family gathered where my mother lives, in Sonoma County, California. Family members have lived there for 45 years. My father's grandmother had lived there earlier in the twentieth century, and my father learned to swim there as a child. I have photographs of my grandmother visiting a vacation spot on Sonoma County's Russian River when she was a child. However, the indigenous Bokeya/Pomo people have called it home for centuries, long before any of my family members visited. Disease decimated the people after Europeans settled in the late eighteenth century. The influx of European Americans in the 1850s led to land dispossession and people being forced onto reservations so the United States government could grant homestead rights to new settlers (Theodoratus 1974). Sonoma County now includes casinos that tribes own and operate. The county also includes wineries and vacation homes and resorts. Some of the people who work in these places rent in shared housing and others are homeowners, all in increasingly expensive homes. According to the Census, as of 2019, 494,336 people lived in the county (United States Census n.d.). People have settled from other countries, some authorized migrants and some unauthorized. The Migration Policy Institute (MPI) estimates that as of 2018, Sonoma County included 29,000 people who were unauthorized (MIP n.d.) While some undocumented people might have entered illegally, others entered legally and overstayed their visas. About $36 \%$ of residents in the county are renters (Sonoma County 
Department of Numbers 2020). Sonoma County has also had more than 2000 people who are unhoused (ASR 2020), living along trails and in brushy encampments where many visitors do not see them. People without stable housing and undocumented immigrants are not legible to many systems of counting and reporting residents. Convention governs how to count, and many contest conventions.

Sonoma County has suffered through terrible fires in recent years, including 2017's Tubbs Fire (Table 1). Sonoma County is only one of the places to be suffering what just about each year turns into the western United States' worst fire season in history. The National Oceanic and Atmospheric Association (NOAA) compiles a list of the disasters in the United States that cause more than $\$ 1$ billion in damage. Below are the fires from recent years according to NOAA. I do not list the 2021 fire season, which has already proven to be very damaging, because it is only September as I write and October is often extremely damaging.

Table 1. Estimate of Damage from Recent Fires.

\begin{tabular}{cccc}
\hline Fire/Drought & Year & Dollar Value of Damage & Acres Burned \\
\hline Western wildfires (including Tubbs) & 2017 & $\$ 19.6$ billion & 9.8 million \\
Western wildfires (including Camp) & 2018 & $\$ 25.7$ billion & 8.7 million \\
Western wildfires & 2020 & $\$ 17.1$ billion & 10.2 million \\
\hline
\end{tabular}

The damage results from both the severity of fires, and where and how people have built in fire zones. In California in 2020, according to NOAA, the acres burnt in California were double what had burned in the previously most damaging fire season, 2018. Insurance payments in hand, people are rebuilding in developments that burned in the 2017 Tubbs Fire (GAO 2020). The utility PG\&E agreed to a $\$ 13.5$ billion settlement in a bankruptcy proceeding to compensate people who had lost homes in multiple California fires, including those in 2017 and 2018 (Penn et al. 2019). The lawsuit and settlement were based on the claim that the utility had been maintaining utility lines poorly, which had sparked the fires that had ravaged the county. The settlement made utility lines more visible. When I visited my family in 2021, before the fire season started, a relative pointed out utility lines tangled with the local oak trees, showing how the lines that could fall in the high winds that come every fall had plenty of fuel for a spark to start a fire. The fires then spread rapidly through Sonoma County's dry grasses, becoming dryer in the West's decades-long megadrought (Mount and Dettinger 2020).

In Sonoma County, homeowners have been discussing the prospect of a rapid increase in insurance rates. Although people wanted to shop for insurance, friends and neighbors cautioned against it, arguing that with the widely recognized risk of fires in the droughtstricken area, many insurance companies would simply refuse to even consider a new insurance client. The fires that have already happened have led to insurance payments for people. Some people received insurance payouts quickly and have rebuilt homes. Others may have moved. Others are awaiting insurance payouts, or payments from the PG\&E settlement.

These discussions reflect climate change in my family's backyard. ${ }^{2}$

Beginning with a disaster leads to different questions about governance than does beginning with the global negotiations, agreements, or reports familiar in the world of displacement and climate change. People in California who live near wildfires are not the people usually featured in discussions of displacement resulting from climate change (Simonelli 2016; Vanhala and Hestbaek 2016). The stories usually told of anticipated displacement are ones of people who live on islands that will disappear due to sea level rise. As Andrea Simonelli has argued (2016), advocates use these stories as metaphors to illustrate climate change and harm. People are canaries in a coalmine, homes will become a mythological lost island, or islands are sinking (Simonelli 2016). In the illustrative stories, no one moves for multiple reasons, although in life people do. In real life, in most places, some people stay behind while others leave. As Simonelli argues, the story of slow-onset 
sea level rise on lands that will become increasingly uninhabitable is more difficult to depict than the story of cohesive communities that will suddenly disappear (Simonelli 2016). No one story will capture places increasingly subject to damaging fires but still habitable, and people's responses. Needing a single story about who is losing home, and how, in a changing climate deflects from the more complex stories that reveal people's different risks and resources, including law. (Arnall et al. 2019). Andrea Simonelli argues that a term for islands subject to sea level rise that better captures the slow onset of disaster is Eventually Uninhabitable Islands (EUI) (Simonelli 2016). There is no term for places that remain inhabitable but require more measures to allow people to live there. People who choose differently because they have different resources, in areas subject to increasingly severe storms, fires, and droughts are not as compelling a story as one of an island that disappears.

The purpose of this paper is to argue that understanding displacement requires beginning from the governing structures already in place for disasters, not from the anticipated losses. Beginning with the local structures will broaden the scope of relevant governance and include private governance, like insurance, or settlements from utility companies. Governance includes lawsuits, like the historic one against PG\&E, since the money could give some people more choices about where to live or how to rebuild. Given the threats, governance includes turning from the trope of the disappearing island and toward the political and governance choices within the much more widespread experience of increasingly intense disaster, like people in Sonoma County, California have lived through. Therefore, this paper draws upon the NOAA reports cited above, a 2020 report from the Government Accountability Office (GAO 2020) that discusses pilot projects for planned climate migration in the United States, and the 2018 National Climate Assessment (NCA). To note disagreement and to point to the institutions that shape choices, the paper also draws upon demographers' analyses of who has moved in the United States after disaster. These analyses offer opportunities to note the structures that often remain out of view. Drawing on these analyses points out another cleavage in scholarship. Climate advocates discuss compensating for losses, imagined as millions of people displaced, mostly in the future. Demographers draw conclusions from past disasters. A cleavage is whether the past predicts future, and what government officials do about that. Bridging the two, the Government Accountability Office has assessed the possibility of pilot programs to move people away from zones facing increasing climate risks.

Discussions of 'disappearing islands' make climate change displacement exotic for the majority of the people in the world who do not live on them. Fleeing across national borders draws the concern of the national security policymaking apparatus in countries who receive people fleeing changing climates (National Research Council 2010, 2013). International migration from uninhabitable places invites reports warning of the need to deepen the thin global governance regimes (Simonelli 2016). While loss, damage, and compensation for poorer countries continues to be hammered out (Vanhala and Hestbaek 2016), people's decisions on whether to move or not depend in part on domestic law.

Studying the 'endotic,' or what is nearby (Hall 2020), instead of exotic, small, islands where few people live prevents climate change and losing home being treated as something that only happens to a few people who live far away. Climate-related disasters worth following include those in wealthier countries, and those close to home. Not everyone can easily leave or resettle where they were. Telling people to leave not only is unlikely in a place with multiple opportunities to object to policy, it tells people to give up, and misses local attachments as an inroad to mitigating climate damage. As the climate writer Mary Annaise Heglar concludes, "home is always worth" fighting for (Heglar 2020). For most people, the place people can fight for is not the globe, but something closer and more tangible. At the same time, of course, the fires and drought affect the millions who live with them, and the people who then live with the smoke. Concern for the vulnerable can include concern for those nearby; people are differently able to leave or adapt. 
The central point of this paper is conceptual: to argue for a research agenda that turns from seeing displacement as dichotomous and grounded only in whether land disappears or not, and from global governance to the complex of local regulations that shape decisions. Environmental governance has a long tradition of following multiple governance levels, including local, and including private regulation. The Nobel Prize winning economist Elinor Ostrom argued that governing is polycentric, or multicentered, including governing of climate change (Ostrom 2009). In the absence of the planned mass relocation climate governance documents imagine, local, national, and private rules shape where people live now, while facing climate-related disasters that do not completely obliterate land. A polycentric lens requires turning from global instruments and planning to the claims people make and the structures that shape them.

\section{Learning from Claims}

Climate reports warn of how many places will become uninhabitable. Beginning an analysis from those reports turns the decision to rebuild in a zone subject to fire into a very strange decision. The legal structures for decisions about where to live in a place subject to climate-related disasters are part of an answer. From a distance, the structures are invisible and the decisions are puzzling. In her agenda-setting article on governing climate adaptation, the political scientist Debra Javeline described the need for research about why people do not move as places become less inhabitable. For her, the problem is one of attitudes and attachment to home, which she describes as against science (Javeline 2014). Framing the problem as one of preferences - that people do not want to leave homewill lead to research strategies centered on individual desires. However, desire entangles histories of dispossession and possession, insurance, work, zoning, homeownership and mortgage policies, immigration practices, and difficulties living unhoused in a place. To say that it is puzzling why people stay also denies the power of fighting for home, which adapting to climate change requires.

Trying to understand the place of law in governing displacement could start with people's experiences, and finding the presence or absence of structures that shape decisions in response to those experiences. The climate scholars Alex Arnall, Chris Hilson, and Catriona McKinnon have argued that beginning with the demand from below rather than the governance regimes from above will better respond to need in climate-related displacement (2019). Arnall, Hilson, and McKinnon follow a conceptual map first described in how people change problems into legal claims. They argue that people must first name their trouble, in this case as climate change, before they can blame an organization for the problem and claim compensation, or demand a change in policy. Asking that people name their problem may well lead to a plethora of reasons for lands becoming difficult to inhabit, including fires, droughts, and housing prices. Naming these multiple sources could lead to multiple points to intervene. Arnall, Hilson, and McKinnon acknowledge that asking people to participate in deciding what to do about places that become more difficult to inhabit runs the risk of imagining cohesive communities that do not exist, where all can agree. Demands could well defer to existing power inequalities. For example, the United States government dispossessed the Pomo people of land less than 200 years ago. The casinos that federated tribes have been able to operate have brought substantial resentment from white people (Davis-Delano et al. 2020). Organizing a trustworthy process across advocacy groups for the unhoused, the tribes, renters, homeowners, and resort owners could be harder than relying on the existing ad hoc response contingent on insurance regulations and options.

Claims-making from below leads to local legal structures influencing decisions, far from the global governance of climate displacement. Structures include insurance companies, and lawsuits against utilities, like PG\&E, or insurance companies that refuse to pay, or lawsuits by shareholders concerned about climate risks. As the sociolegal scholar Kim Bouwer has argued, all litigation now happens in the context of climate change (Bouwer 2018; Marshall and Sterett 2019). ${ }^{3}$ Diagnosing how people experience the structures shap- 
ing their lives allows ways to intervene to be found. Viewing from afar, without including people who decide what to do in situations more ambiguous than a disappearing island, may not (Latour 2005).

Claims-making from below also respects the people who are deciding what to do. People are experts in living their own lives, even if it means living with difficult housing decisions. People can describe what they are deciding to do. As the feminist sociologist Dorothy Smith argues, "we are expert practitioners of ... the way [our lives] are just the way they are" (Smith 1987, p. 110). Our everyday lives do not require that we know "how they are knitted into the extended social relations of a contemporary capitalist economy," and living our lives will not reveal these relations (Smith 1987, p. 110). Beginning from claims-making, which Arnall, Hilson, and McKinnon argue could potentially reveal more about managing displacement than beginning with the international governance system, does. Beginning with the decisions people face still requires linking of claims to the structures and histories that influence how much choice people have in staying or leaving.

The paper turns next to noting how authoritative documents describe the risks of displacement, and alternatives in adapting and staying where one is. The paper then synthesizes scholarship on who leaves an area after disasters, and how much more complex contexts are than the trope of disappearing islands captures. Next, it argues for following the histories and policies in state, local, and national governance. These decisions and the structures they reproduce are the context for decision making about where to live.

\section{Climate Change, Extreme Events, and Changing the Image}

\subsection{Disappearing Islands and Adapting in Places That Become More Difficult to Inhabit}

The National Climate Assessment in the United States argues climate changes will lead to displacement. They mention specific communities, capturing the 'disappearing islands' trope so prevalent in climate discussions (Simonelli 2016). There will not be anything to govern once islands disappear, so the disappearing islands themselves define the demand for acting on displacement. However, the NCA also describes much broader risks of displacement, largely centered on coasts:

"Many millions of Americans live in coastal areas threatened by sea level rise; in all but the very lowest sea level rise projections, retreat will become an unavoidable option in some areas of the U.S. coastline". (USGCRP 2018, Ch. 8)

The 2018 National Climate Assessment is organized by regional threats, in addition to specific threats to coastlines. The chapter on adaptation lists illustrative mitigation measures. The NCA warns of retreat but acknowledges people will continue to live in places. The NCA references wildfires in multiple places when discussing United States regions. In the chapter on the Southwest, its key messages 2 and 4 mention fire, in threats to ecosystem services and to indigenous people (USGCRP 2018).

The chapter on adaptation discusses multiple organizations that shape adaptation, including engineering, finance, and the military. The illustrations in the chapter all concern water and managing flooding (Louisiana, Miami Beach, New York City, the Gulf of Mexico, Fort Pulaski, on an island in Georgia, and Norfolk, Virginia). For example, the NCA does describe some of what New York City has done since Superstorm Sandy:

"New York City has reduced its potential future flood impacts by relocating a limited number of households out of the most flood-prone areas (reduced exposure), raising the height of some structures above the ground so they suffer less damage from any flooding (reduced sensitivity), and training the officials responsible for revising building codes and land-use policies to use the most up-to-date estimates of flood risk (increased adaptive capacity)" (ch. 28, at "Adaptation Action to Reduce Risks").

Even the NCA, which warns of threats to millions of people who will have to retreat from coastlines, finds that moving is only one response among many to govern in the face of increasingly severe storms. Insurance rates are as likely to govern decisions about 
staying and leaving as either global or national public governance mechanisms (USGCRP 2018, ch. 28; Sawada and Yoshido 2017). The NCA lists many different ways of governing adaptation. To add another factor, the enforcement of immigration law would also matter. People who are not legally resident might well care about which states cooperate with federal immigration officials, and, for example, even which states allow undocumented people to get driver's licenses and state-issued identification. As of 2021, 17 of 50 states allow it (NCSL 2021). Without a driver's license, people cannot work and care for family. The domestic law that shapes whether people stay or go includes states' laws for undocumented people.

As climate change increases the likelihood and severity of fires, heat waves, and other extreme events, experts also agree that multiple possible tactics could mitigate the damage, as they can for floods. For fires, mitigation includes improving forest management through proscribed burns, working with indigenous people in forest management, and managing timber harvest for conservation by thinning trees (Abatzoglou et al. 2021; Marks-Block et al. 2021; Stephens et al. 2020). Like changing building codes in flood zones, it may not be enough.

In telling a specific story about displacement, the NCA discusses Isle de Jean Charles, a relocated community from Louisiana, at great length (USGCRP 2018, ch. 28). Isle de Jean Charles and some other small villages and communities fit the trope of a disappearing island. Rules and contests over rules also facilitate resettling. The federal government facilitated moving the remaining few inhabitants of Isle de Jean Charles under a grant in 2016 (GAO 2020) Some people have filed lawsuits suing for compensation for land loss. Lawsuits highlight some losses and make the disappearing islands or villages more nationally visible. The Alaskan villages of Shishmaref and Kivalina are relocating, and Kivalina was the subject of a failed lawsuit about the damage it has suffered as a result of oil companies' business (Bronen and Chapin 2013). Losses include the Marshall Islands, which, after many years as a United States territory, is now an independent country. Absent a general policy to facilitate moving, people move to the United States from the Marshall Islands because they have a right to settle, based in the Marshall Islands' history (Hirata 2015). However uninhabitable places become, people decide given the changes and the legal structures they encounter. Immigration in response to storms relies on existing connections and networks, which help people to resettle (Esnard and Sapat 2014; Mahajan and Yang 2020). Grants, lawsuits, rights to immigrate: all make it easier or more difficult to relocate.

Governance about how to manage displacement, both within the United States and in global discussions, has less often worked out what to do about places that burn every year, or flood repeatedly, where people will stay (Simonelli 2016). The National Climate Assessment describes multiple adaptations in cities subject to flooding; they are local and do not summarize readily into one theme, unlike moving. Finding points for intervention, or figuring out the problems, requires turning to the governance people do experience. That means compensation, including from lawsuits or insurance, or the zoning that allows people to stay in place or leave. The places people can stay in or leave include not only small cohesive communities that could suddenly disappear under water, but sprawling areas of the American West and Australia that can burn, but still be habitable.

Fires and the megadrought the western United States has been experiencing in the twenty-first century can make it more difficult to live there. It is not impossible. Retreat is one response, but not the only one. The plants and animals that can thrive in different places change with climate change, but the places do not disappear (Camacho 2010). However incomplete and unevenly available mitigating damage from disaster is, it is possible. People can stay even in places that are not as welcoming as they once were. People decide whether to leave both in the United States and in the islands subject to more intense storms. There is no guidance determining when a place has become uninhabitable, and no imagining a central authority that could determine it for something other than land that has disappeared. Local laws and distant opportunities and laws push or pull them. 
For example, people from the Marshall Islands have a right to settle in the United States, and they have (Hirata 2015). People who live on continents can suffer through increasing numbers of intense heat waves. People are differently able to respond to heat waves and stay safe and comfortable. For those who can afford it, leaving for some of the year or increasing the use of air conditioning can make places inhabitable. ${ }^{4}$

In her article on climate change and political science (2014), Debra Javeline, distinguishes adapting from "coping, or employing short-term remedies to immediate problems" (Javeline 2014). Adapting, argues Javeline, implies more collective policy choices that recognize climate change and plan for what to do about it, not immediate local responses to increasingly severe disasters. Despite Javeline's distinction between coping and adapting, in the absence of collective decisions to adapt to climate change, coping with climate change is adapting in practice. People are compensated for damage, including displacement, through a complex of local laws and bureaucracies. Distinguishing current practices from real adaptation is likely to defer ever finding adaptation that meets the hoped-for criterion of planning.

The NCA's statement that millions might have to leave sounds an alarm to call for planning. It offers hope by pointing out what cities have done. A different office, charged with different responsibilities, responded to Congress's request to investigate what planned relocation would look like. In the United States, the Government Accountability Office (GAO), the "investigative arm" for Congress, issues reports upon Congress's requests. In July of 2020, the GAO reported on pilot plans for climate displacement. To have the GAO report on specific places in a report changes climate change from something to sound the alarm about, as the NCA does, to something that requires practical management. It domesticates climate displacement, taking it from the exotic to the endotic.

The GAO talked to people in four communities. Three were communities at risk from rising seas, including Newtok, Alaska, an island community of 400 people, the oftdiscussed Isle de Jean Charles Louisiana (with 85 people), and Smith Island, Maryland. Valmeyer, Illinois, which suffered extensive flooding in Midwestern floods of 1993 (far from the continent's coasts), also received a mention because community members decided to leave. Even in communities that have suffered tremendous losses, the GAO found very little support for moving in response to increasing risks of climate related disasters (2020). Money is not available to help. The federal government has had other priorities, and the local governments do not have the resources to pay to relocate people. The islands the GAO report writes of which are moving-Isle St Jean and Newtok, Alaska—have taken decades to move. The one community subject to fire and drought discussed in the report was Santa Rosa, California, which had suffered in the 2017 Tubbs Fires, and the 2019 Kincade Fire. With about 175,000 people, Santa Rosa is the largest city in Sonoma County. According to the GAO, Santa Rosa officials were not interested in discussing a planned retreat (GAO 2020, pp. 23-24). The GAO reported that first, California had a housing shortage and city officials did not want to contribute to it. Second, they argued, people would not be interested (GAO 2020, pp. 23-24). Though the report did not discuss the problem of local revenue, local governments need their property tax base; helping people to move elsewhere would only limit county and city governments' revenue collection when they still need to run schools, firefighting, and police. The lack of interest in relocating as reported by city officials does not bode well for widespread voluntary climate migration initiated by government officials. Arnall, Hilson, and McKinnon argue for following the claims people make, rather than decisions from the top down. Principles of consent when governing require thinking through layers of private business regulation, engineering design, and laws from multiple jurisdictions, all influencing decisions. Disasters have not led to collective demands for resettlement in places that have not disappeared, outside of small villages. 


\subsection{Anticipating Displacement and Measuring Movement}

Climate scientists and climate advocates argue that many people will need to leave their homes. The National Climate Assessment states that histories of whether people have moved in response to disaster are irrelevant to coming climate change (USGCRP 2018, ch. 28). Because mass planned displacement due to climate has not yet happened in the United States, and because people can continue to live where they have been living, climate advocates' preferred solution of moving many people requires persuading people they would be preempting bigger problems, which people are often reluctant to do. Global negotiations about loss and damage and problem statements like the United States' NCA emphasize the importance of imagining future losses (USGCRP 2018, ch. 28; Vanhala and Hestbaek 2016) and taking practical steps to meet them. Practical steps look fantastical when the problem is not evident to people (Clarke 1999). Very prominent public problems where the federal government was wrong do little to persuade people to listen to officials. ${ }^{5}$

In contrast, demographers begin by believing the best predictor of what people do is what people have done in the past. They conclude that people largely have not moved, so massive climate migration is unlikely within the United States. Skepticism about imagining the future meets empirical analysis of whether people have moved, and how far away they have moved in the past after disaster in the United States. Whether or not people will have to move in much greater numbers, what demographers and economists have found does show the rules and resources that have shaped decisions. Assessing what people do after storms is difficult, and demographers and economists have assessed where people live or what happened to their personal finance through surveys, credit records, mortgage records, and, more recently, cell phone data or social media data. Public policies about disaster relief and other resources are included in models describing who moves and who does not after disaster.

Global governance for displacement assumes land will disappear. People on disappearing islands will all equally have to move with climate displacement. Demographers, whose analyses I synthesize below, point out that people who suffer through disasters make different decisions depending on the resources they have. Both economists and demographers have found that people with greater resources may be more likely to move. At minimum, they can have more choices about whether or not to move. Even if people move, though, analysts discussed below expect that land will be available for rebuilding.

In the United States, after disasters that have struck since 1920, some people have left the counties in which they lived. Leah Boustan and her colleagues' study of out-migration after disaster examined disasters in the United States. They found that severe disasters led to greater out-migration. With the increasing numbers of disasters since 1980, even milder disasters lead to people leaving a county, they argue. People are more likely to leave after hurricanes and fires than after floods (Boustan et al. 2020). Since the study did not track the differences in public policy and insurance, the authors speculated broadly about why the differences in an area's growth depend on type of disaster, or the reasons for declining growth. One answer may be a governance decision: rebuilding in flooded areas is subsidized by flood insurance (Strother 2018). Rebuilding in burnt areas is not. Disaster does interrupt what economists otherwise expect: that growing areas would attract more people. Boustan and her colleagues found that after disaster, people leave even areas that are growing. Finally, the study found that poorer people are more likely to stay behind (Boustan et al. 2020). The demographer Elizabeth Fussell and her colleagues found that even after Hurricane Katrina, people returned to the Gulf Coast. They concluded that the risk of climate displacement is overstated because people have settled near where they fled. Accepting existing incentives as shaping decisions would mean investing in rebuilding an area.

The premise of the study by Leah Boustan and her colleagues is that people would ordinarily rebuild after disaster, not that places experiencing disaster become uninhabitable. Boustan and her colleagues argue that a fire can make a place more affordable by leading to a 'reset' that allows rebuilding of denser housing stock, leading to a decline in prices. 
Areas can become more attractive because of declining housing prices. Their story of a reset does not unpack the governance decisions involved in everything from insurance rates to zoning decisions local governments would make. Unlike climate reports, they do not treat disaster-struck areas as uninhabitable over the long term, or subject to a collective decision that rebuilding should not happen. By assuming that people would rebuild places, they exactly counter the climate governance people who argue that people must leave increasingly dangerous places. The surprise for the scholars is that places suffering through major disaster do not grow afterward, given their argument that a 'reset' should mean lower housing prices and growth (Boustan et al. 2020). In a study of all hurricanes and floods between 1980 and 2012, the demographer Elizabeth Fussell and her colleagues (2016) found that hurricanes and tropical storms suppress growth in the most populous counties experiencing these disasters, but only in the year of the disaster. After that, repeated hurricane events are associated with increased growth in counties with more people (Fussell et al. 2017). Both Boustan and her colleagues and Fussell and her colleagues found that severe disasters do lead people to leave, just not in large numbers.

Hurricane Katrina is the biggest single climate displacement under current governance. The 2005 hurricane initially displaced more than 450,000 people, and five months later, the city included 279,000 fewer people than it had before the storm (Gallagher and Hartley 2017). The Dust Bowl in the 1930s saw large-scale depopulation of the Plains States in the 1930s; some part resulted from the collapse in crop prices, beginning in the 1920s (Long and Siu 2016). Home ownership, insurance, and disaster assistance are also different in the twenty-first century from what they were in the 1930s.

The economists Justin Gallagher and Roger Hartley found that after Katrina, homeowners in flooded areas used insurance payouts to pay down their mortgages rather than rebuilding (Gallagher and Hartley 2017). Mortgage companies could require mortgages to be paid down, and rebuilding in flooded areas in New Orleans was more expensive than the insurance could cover (Gallagher and Hartley 2017). Paying down a mortgage could mean returning or leaving. Gallagher and Hartley argue that people who paid down mortgages at the behest of banks moved. They could not return to their destroyed homes.

Mortgage payments and banking decisions suggest how people's choices were constrained, but do not directly say whether people stay or go. In another study of low-income African American women, homeowners were more likely to return than renters (not move), and renters were more likely to return than people who had been in public housing, often through the federal voucher program summarily called 'Section 8. '. The difference between renters and homeowners was private insurance (Fussell and Harris 2014). Insured homes could be places to live. Neither renters nor people who had been in public housing could conjure housing that was no longer there. The decisions people make depend on existing legal and political structures, including flood insurance and property taxes. Change the regulatory structures, including the incentives they embed, or change the disasters, and decisions might change. Past behavior in existing governance cannot settle what would happen if flood insurance stopped subsidizing rebuilding, as Congress tried to do before the real estate industry mobilized against the changes (Strother 2018). While Fussell and others conclude the risk of climate displacement has been overstated, an alternative conclusion could be that institutions do not have responses to disasters that facilitate moving and moving will be necessary. The inability to agree on an anticipated future and act upon it leaves people to the resources they have after disaster. Even after Hurricane Maria, which struck Puerto Rico in 2017, the best estimate is that the population declined by between $4 \%$ and possibly up to $17 \%$ about a year after the hurricane (Acosta et al. 2020).

Governing with insurance is a common thread between the findings over multiple disasters by Boustan and her colleagues, Fussell's findings about Hurricane Katrina, and the economists Justin Gallagher and Roger Hartley's findings (2017). Recognizing the centrality of insurance to homeowners, California has issued moratoria against insurance companies dropping fire insurance policies. It has a state insurance program for those who cannot get private insurance, though coverage is expensive and limited (Flavelle 2020). 
Understanding how insurance shapes choices requires a close assessment of what insurance requires. The out-migration that Boustan and her colleagues found was of people who were more affluent. Fussell's entire sample comparing homeowners, renters, and public housing residents was of lower-income African American women (Fussell and Harris 2014), and they found that homeowners were more likely to return than to leave. These studies relied on different samples of different people, from lower-income African American women to all homeowners, to all people across multiple disasters. Bridging the findings could be that people who received insurance payouts after Katrina paid down mortgages. Those who could return did; perhaps those whose homes were completely destroyed did not. Understanding how or why homeowners or renters move or stay requires understanding insurance and banks' requirements, and housing availability.

Insurance prices risk, including risks of climate-related disaster. Therefore, homeowners get signals about how difficult it will be to live in an area from insurance prices. In the United States, insurance pricing differs between flood and fire insurance. Flood insurance relies on maps drawn with public data. Insurance rates are set according to these maps. Flood insurance is also a public program in the United States, subsidizing the prices people pay (Pralle 2019; Strother 2018). Since the maps rely on publicly available data and projections about flooding, they are subject to public challenge in a way that fire maps are not. People in more affluent areas who wish to stay where they are challenge the maps and the higher insurance rates they would bring (Lea and Pralle 2021; Pralle 2019; Strother 2018). They do not plan to leave, and they try to limit increases in insurance. Differences in resources, including legal resources, differentially allow people to decide how to cope with rising seas and other problems.

Government assistance also makes it more or less possible to move. Disaster-specific assistance is temporary. After Katrina, disaster-related assistance may have allowed some poorer people to stay away for longer (Graif 2016). After disasters, the federal government has extended unemployment insurance and public health payments. After Katrina, these programs proved more valuable than disaster assistance (Deryugina 2017). Other social insurance programs pay people for reasons other than disaster, so payments could be more reliable. National disability insurance pays people a monthly sum if they qualify as too disabled to work. Old-age social security payments pay the elderly if they were employed in programs that qualified. Longer unemployment insurance for people who left jobs and home after a disaster could open more choices about what to do.

The exemplars for climate displacement in climate scholarship — the disappearing islands-do not match well with disasters and habitability in the continental United States. Islands do not disappear, but can see more recurrent flooding, as Smith Island in Maryland does (GAO 2020). Most people subject to storms, floods, and fires do not live on islands. They live on land that will not disappear. The land may be more difficult to live on as extreme events intensify. Insurance, zoning, and settlements from lawsuits will all guide where people move after disaster. If migration relies on guiding decisions with available resources, including insurance payments, zoning, and changing building standards, more affluent people could have more choices about whether to rebuild or leave. Whether people see themselves as having more choices would require studying claims-making from below, since insurance could offer choices or be required for mortgages, and settlements when utilities are held responsible could come years after the disaster, and be enough to matter or too small. Based on analyses of what happened after Hurricane Katrina, the demographer Elizabeth Fussell and her colleagues argue that within the United States, climate change is unlikely to require mass relocation.

The finding that many people return after climate-related disaster, and homeowners may be the most likely to return, does not address climate warnings about displacement. Instead, these findings lead to the conclusion that existing mechanisms do not accurately price coming risks. The finding that people in communities subject to devastating fires and floods are not interested in relocating means consent and collective claims-making do not yet lead to naming climate change as a reason to move. People return home for resource 
reasons if no others, and for now, for many, home is a place, not the whole earth. The fights for home follow the incentives that insurance and other available resources set up.

If the goal of authors of climate reports is to urge governments to compensate the people who need it most, insurance and lawsuits after disaster do not answer the call. If compensation or rights concerning displacement are for those who most need it, and cannot leave without it, they are for the renters, those in public housing, and those without housing. They will not get compensation in existing systems after disaster. Even settlements from lawsuits, such as the PG\&E lawsuit, compensate people according to what they have lost. Homeowners have greater compensable losses.

If the purpose of compensation is instead to get people to leave rather than compensating for disaster, not because a disaster displaced them but because inhabiting a place has become too risky, compensation mechanisms need to do something other than pay people for property. Renters and people in public housing have fewer compensable losses. Leaving is harder in the absence of support. Histories of dispossession and the capacity of the more affluent to appeal administrative decisions (Lea and Pralle 2021), gain greater compensation, and buy materials that mitigate damage would do little to build trust.

The model of disappearing islands is the wrong model for the problem of loss, but it is easier to capture than the reality of different decisions when people have different resources. People live in places after disasters, sometimes mitigating risk, and places lose people over time, depending on the choices they have-compensation or assistance in moving could come after climate-related disaster. Arguing for rights for those forced out may be misdiagnosing a problem, if people decide based on multiple factors. As Fussell and Boustan and their colleagues have argued, within the United States, even catastrophic disasters have not induced most people to leave an area, or not far away and not for long (Curtis et al. 2015).

If governing displacement is instead to encourage people to leave an area that is increasingly uninhabitable (and expensive to maintain, given the demand for disaster response) as a result of longer fire seasons, more extreme floods, and increasing heat waves, governance requires more than recognizing rights for people who have fled. Governing requires rights and compensation for people some authority imagines should move, and persuading people they should. As the GAO explained, in the United States, city officials in a city devastated by the historic Tubbs Fire in 2017 did not believe community members would want to move. The United States has had no programs to aid in moving because of climate-related disasters. Displacement or relocation has been the biggest problem for disadvantaged minorities, whether from the Trail of Tears (Norgren 2004), freeway projects in cities, and the Japanese American internment during the Second World War (Daniels 2004), again, doing little to build trust.

Demographers expect growth after disaster, but did not find it after Katrina, a mass displacement in the United States. Some have stated that past disasters indicate displacement is not likely to be a big problem in a changing climate. In contrast, climate reports predict that people will abandon places, and governments must ease the cost of leaving. Neither takes into account the politics and rules influencing decisions, and that they could change. If people did not leave after disasters because they had no place to move to, concluding that people do not move because they have not does not answer predictions of need. If people do not want to move and see paying higher insurance costs, or contesting insurance choices, or changing building materials as possible, that climate reports say people should leave does not answer the disbelief. Threading the needle between a future people have not experienced and a past when people have not moved requires accounting for the domestic governance structures that influence how people decide. After all, as the GAO reported, moving two small communities in the United States has taken decades (GAO 2020). 


\section{Governance: Global Principles, National and Local Laws}

The global governance regime for climate-related displacement is thin, as Andrea Simonelli has argued (2016). She argues that failure to integrate displacement into international climate change governance constitutes a governance gap. Climate-related displacement does not neatly fall within the purview of organizations responsible for refugees or for humanitarian assistance. Simonelli notes the Geneva Convention on Refugees, and acknowledges, as others have, that climate-related displacement does not fit the Convention's definition of refugees well (McAdam 2010; Simonelli 2016). Categorizing people who leave home because of climate-related disasters (Esnard and Sapat 2014) or are displaced due to climate faces all the difficulties of categorizing other migrants across borders. A governance gap in international institutions allows myriad other existing laws to fill in.

The 1998 Guiding Principles on Internal Displacement (GPID) could more closely match the circumstances of leaving after climate-related disasters than the refugee convention does. Even so, the GPID elevate choice and consent, and the right of return. The target of the GPID is a government, not the tangled governance web of insurance, social welfare transfer payments, and housing availability. Like the demographers, the GPID envision places being rebuilt. The GPID recognize that people often move within countries when fleeing war and disaster (Kälin 2008, 2010). The GPID describe decisions about whether to stay away from the disaster site or return home as being up to individuals. Rights include the right of return as soon as possible. The GPID's guiding assumptions are the choices individuals can make, not massive, planned relocation. Areas are always potentially habitable, as they are in the studies concluding that people do not usually move far away after disasters in the United States (Fussell and Harris 2014).

The GPID rely on some of the mechanisms shared across international instruments: a special concern for the vulnerability of women and children, and a right to judicial review (Kälin 2010). The GPID govern the legal subject embedded in human rights documents: the person who chooses what to do, and whose choices are autonomous (Merry 2006, p. 137). The GPID are therefore framed not to protect people permanently leaving home, as reports on climate change envision happening, but for those away temporarily. They do not anticipate places being uninhabitable over a long term.

Even without being binding and without fully capturing what climate change could require, guidelines can organize normative criticism of what governments do. After 2005's Hurricane Katrina, the think tank Brookings Institution held a conference on internal displacement (Sturgis 2008), and advocacy groups framed the failure to safely bring people back to the Gulf Coast as a failure to meet obligations under the guidelines (Kromm and Sturgis 2008). Criticism grounded in an international document framed within professional legal knowledge and claims implies that it represents not a particular point of view, but a professional consensus about the legal needs people have. When drafting international rights-based documents, drafters borrow from already agreed-upon language used in other documents, which speeds agreement by drawing on professional experience (Merry 2006, p. 43). Language signals a common enterprise rather than instrumental effectiveness. For example, a right of judicial review is uncertain and costly, so it may not be an especially effective remedy for government wrongdoing (Sterett 2015; Sterett and Mateczun 2020). Nevertheless, including a right of judicial review signals participation in the common enterprise of limiting governments' arbitrariness. It does not envision constraints and abilities radiating from multiple agents, private and public.

Summarizing the difficulty of making a collective decision to move as "attachment to home," and wrongheaded in the face of a changing climate, takes for granted all the rules and structures that keep people in place. It misses the decisions to build with different materials the next time, or to comply with stricter insurance requirements, or the inability to find housing elsewhere. In Sonoma County, it misses the tie between land and livelihood for the Pomo and other tribes that operate casinos, as well as for many others. It misses the utility regulation, insurance and its affordability for homeowners, support for homeowners via deductions for mortgages, the land use zoning decisions the city makes tied in turn 
to the need for property taxes (Martin 2008), in turn tied to state decisions to subsidize fire insurance (Flavelle 2018), and whether the state of California will cooperate with the federal government to deport people. The legal reasons people stay-the insurance, the zoning, the driver's licenses-could remain in the background, leaving individual attitudes and missing how law organizes preferences. Following how law constitutes experience allows finding points to intervene in governing where people live in the absence of a comprehensive plan.

Table 2 lists embedded legal and political histories relevant to decision making about whether to live in Sonoma County with the increasing risk of extreme events. The list is not complete; it illustrates the different statuses people bring to experiences in disaster. The table below for example, does not begin to touch on the tax status and wealth of those in the tech industry, whose beneficiaries are prominent in California.

Table 2. Legal and Regulatory Structures in Displacement.

\begin{tabular}{|c|c|c|}
\hline Regulatory/Legal Domain & Level of Government & Illustration \\
\hline Homesteading and tribal dispossession & National & Bokeya/Pomo people: reservations and businesses \\
\hline Immigration & National & $\begin{array}{l}\text { Asylum/temporary protected/permanent resident/visa } \\
\text { statuses }\end{array}$ \\
\hline Immigration & State and local & $\begin{array}{l}\text { Cooperation with national government in deportation; } \\
\text { granting driver's license }\end{array}$ \\
\hline Immigration & State & Drivers' licenses for undocumented people \\
\hline Securities & National & $\begin{array}{l}\text { Shareholders contesting representations about utility safety } \\
\text { practices }\end{array}$ \\
\hline Insurance & National/state/private & $\begin{array}{l}\text { National Flood Insurance Program, subsidizing rebuilding in } \\
\text { flood zones; pricing; state decisions to subsidize pricing in fire } \\
\text { zones; company-imposed standards for property maintenance }\end{array}$ \\
\hline Tax law & National & Deductions for mortgage interests \\
\hline Housing and unhoused people & National/state/local & $\begin{array}{c}\text { Section 8; state housing policies in disaster; policing } \\
\text { unhoused people }\end{array}$ \\
\hline Zoning & Local & Rebuilding housing in areas at high risk for fires and floods \\
\hline
\end{tabular}

These structures shape people's decisions, but many are only visible once daily life stops working because a fire or heat wave makes living in a place more difficult. Decisions and experiences are often individual, or within family and friendship networks. People access insurance payments as individuals, even if they compare their experiences with others. Renters or their proprietors may decide not to renew leases when rent rises, or if compensation is offered for housing. A utility can agree to a structure of payments for a large group of people, but those paid experience it individually. For those who are undocumented, partial documentation allows people to move more freely. It is also confusing, particularly because the difference between federal and state and local legal responsibilities are not clear to people (Coutin 2000). People who are only partially legible to state systems, such as people without housing or people who are not fully legally present under immigration law, leave an area individually rather than through collective planned migration.

Multiple laws enacted at multiple levels affect whether and how people leave because of climate change. Immigration law is national, though the state of California and officials in Sonoma County, California have declared that collaborating with national immigration officials not a priority. People who have stayed longer than their visas allowed or were never legally physically present remain not legally present according to the national government, and they have no way of claiming asylum or otherwise making their status legal. On the other hand, they are likely to have family members in school, and drivers' 
licenses, and otherwise demonstrate legal presence. The liminal legality people have in a place can make the ties they have for work and family more important.

This thicket of legal rules organizes people's preferences about staying in a particular place, including one that frequently experiences climate-related disasters and is likely to suffer through more. This thicket of rules intertwined with how people work with them is not the level at which migration law, climate change, and displacement are usually discussed. International instruments negotiated between national states speak the language of human rights. Mechanisms to compensate people for losing their homes due to sea level rise and increasingly intense storms center on the distinct island communities getting washed away, and the minimal leverage poor countries have to insist on compensation from wealthier ones. Compensation is collective, not individual. In the United States, where there is little prospect for a massive investment in relocating people who do not want to be relocated, compensation is individual and after disaster, not prospective anticipating increasing harm.

\section{Conclusions}

As global institutions assess climate-related displacement and what to do about it, climate-related disasters continue. International agreements for compensation center on compensating countries, not individuals, and island countries, not people subject to heat waves and fires (Lees 2017; Vanhala and Hestbaek 2016). Global governance does not currently categorize those who flee a changing climate. However, if people with few resources do not usually move far from home under current practices, a challenge is to assist in planning for displacement when people do not plan on moving. Even within wealthy countries, parts of the Earth are becoming increasingly difficult to inhabit, and people are not equally able to move. Local governments can wish to attract people and, in the United States, the need for a property tax base will shape who they wish to draw. After the pandemic, resources increasingly include the ability of some people, largely those who already have greater resources, to work from anywhere with an internet connection. If people do not need to live where they work, climate vulnerabilities—or bad weather-can be among the problems they consider when deciding where to live. Accommodating the increased difficulty of living in places requires encountering the multiple regulations and resources that encourage people to stay or go. The only way to find them is by following people and rules in places.

People have legal statuses and other resources, all differently embedded in the law, in a way that is likely to matter for whether one moves or stays after disaster. People are not one homogeneous community, as the story of disappearing islands implies. For those who own homes, the cost of insurance and, if a home burned, how and whether insurance pays, and how much, will influence decisions about rebuilding in fire zones. So will whether one can insure a new home. For people who rent homes, jobs, rental prices, childcare, and schooling will all contribute to deciding whether to stay or leave. People who are fully legally resident, or even citizens, have greater choices available about where to live than people who do not.

People fight for a place, whether the fights are individual or collective, grounded in insurance or in the attachments to home that conservation activities foster. Home is always a place, not the earth as a whole. Dismissing as irrational the attachment to home that hinders the massive relocation climate reports imagine must soon be necessary anticipates massive relocation programs being unlikely. Many people in places at risk do not welcome relocating away from land that is still habitable, however difficult it is to live on (GAO 2020). Political officials will fight against losing people who contribute to taxes. Fostering habitability could center on the different capabilities people have for moving or staying. Following claims will track social insurance programs, housing affordability, and immigration rules. These problems could bring together more people than centering climate change does. 
Funding: This research was partially funded by NSF \#0555117.

Institutional Review Board Statement: Not applicable.

Informed Consent Statement: Not applicable.

Data Availability Statement: Not applicable.

Acknowledgments: I am grateful to reviewers of earlier versions of this manuscript for their comments, and to the editors. I am also grateful to Maya Sterett for her comments. Adebola Daramola assisted with editing.

Conflicts of Interest: The author declares no conflict of interest.

\section{Notes}

1 Susan M. Sterett is Professor in the School of Public Policy at the University of Maryland, Baltimore County.

2 Acknowledging Leah Stokes, who has written about climate change in her backyard, in Santa Barbara, California, which suffers wildfires and resulting mudslides after rainstorms (Stokes 2018). Natasha Behl (2019) has argued that pretending distance from a problem when we are not promotes a belief that we are outside the world we study when we are not.

3 PG\&E was to pay for some of the settlement from shares. As share prices change, so does the value of the settlement. Shareholders have also brought lawsuits against businesses, including the utility, for not protecting the value of the company against climate risks, a type of climate litigation that has been spreading (Kohlatkur 2019; LaCroix 2019; Peel et al. 2019).

$4 \quad$ Kim Stanley Robinson opens his climate change novel Ministry for the Future with a story of a killing heat wave in India (2020) The failure to prevent death in poor countries haunts the protagonist for the rest of the novel. Since planning for what people have not experienced meets skepticism and all the reasons people have not to move, displacement works via responding to climate-related disasters and people's ability to move.

5 In 2002, the federal government assured the people of the United States that Iraq held weapons of mass destruction, and therefore the federal government had to invade Iraq. National intelligence was incorrect, and officials never found weapons of mass destruction.

\section{References}

Abatzoglou, John T., Caroline S. Juang, A. Park Williams, Crystal A. Kolden, and Anthony LeRoy Westerling. 2021. Increasing Synchronous Fire Danger in Forests of the Western United States. Geophysical Research Letters 48: e2020-GL091377. [CrossRef]

Acosta, Rolando J., Nishant Kishore, Rafael A. Irizarry, and Caroline O. Buckee. 2020. Quantifying the dynamics of migration after Hurricane Maria in Puerto Rico. Proceedings of the National Academy of Sciences of the United States of America 117: $32772-78$. [CrossRef] [PubMed]

Arnall, Alex, Chris Hilson, and Catriona McKinnon. 2019. Climate Displacement and Resettlement: The Importance of Claims-Making 'from Below'. Climate Policy 19: 665-71. [CrossRef]

Applied Survey Research (ASR). 2020. 2020 Sonoma County Homeless Census Comprehensive Report. Available online: https: / / sonomacounty.ca.gov/CDC/Homeless-Services/Homeless-Count/ (accessed on 28 June 2021).

Behl, Natasha. 2019. Gendered Citizenship: Understanding Gendered Violence in Democratic India. New York: Oxford University Press.

Boustan, Leah Platt, Matthew E. Kahn, Paul W. Rhode, and Maria Lucia Yanguas. 2020. The Effect of Natural Disasters on Economic Activity in US Counties: A Century of Data. Working Paper \#23410. Cambridge: National Bureau of Economic Research.

Bouwer, Kim. 2018. The Unsexy Future of Climate Change Litigation. Journal of Environmental Law 30: 483-506. [CrossRef]

Bronen, R., and F. S. Chapin 3rd. 2013. Adaptive Governance and Institutional Strategies for Climate-Induced Community Relocations in Alaska. Proceedings of the National Academy of Sciences of the United States of America 110: 9320-25. [CrossRef] [PubMed]

Camacho, Alejandro E. 2010. Assisted Migration: Redefining Nature and Natural Resource Law Under Climate Change. Yale Journal on Regulation 27: 171.

Clarke, Lee. 1999. Mission Improbable: Using Fantasy Documents to Tame Disaster. Chicago: University of Chicago Press.

Coutin, Susan Bibler. 2000. Legalizing Moves: Salvadoran Immigrants' Struggle for U.S. Residency. Ann Arbor: University of Michigan Press.

Curtis, Katherine J, Elizabeth Fussell, and Jack DeWaard. 2015. Recovery Migration After Hurricanes Katrina and Rita: Spatial Concentration and Intensification in the Migration System. Demography 52: 1269-93. [CrossRef] [PubMed]

Daniels, R. 2004. Prisoners without Trial: Japanese Americans in World War II. New York: Hill and Wang.

Davis-Delano, L., R. Galliher, K. Carlson, A. Eason, and S. Fryberg. 2020. White Opposition to Native Nation Sovereignty: The Role of 'The Casino Indian' Stereotype and Presence of Native Nation Gaming. Du Bois Review: Social Science Research on Race 17: 55-80. [CrossRef]

Deryugina, T. 2017. The Fiscal Cost of Hurricanes: Disaster Aid versus Social Insurance. American Economic Journal: Economic Policy 9: 168-98. [CrossRef]

Esnard, Ann-Margaret, and Alka Sapat. 2014. Displaced by Disaster: Recovery and Resilience in a Globalizing World. New York: Routledge. 
Flavelle, Christopher. 2018. Why Is California Rebuilding in Fire Country? Because You're Paying for It. Available online: https:/ / www.bloomberg.com/news / features/2018-03-01/why-is-california-rebuilding-in-fire-country-because-you-re-paying-for-it (accessed on 28 June 2021).

Flavelle, Christopher. 2020. California Bars Insurers From Dropping Policies in Wildfire Areas. The New York Times, November 5. Available online: https://www.nytimes.com/2020/11/05/climate/california-wildfire-insurance.html (accessed on 7 September 2021).

Fussell, Elizabeth, and Elizabeth Harris. 2014. Homeownership and Housing Displacement After Hurricane Katrina Among LowIncome African-American Mothers in New Orleans. Social Science Quarterly (Wiley-Blackwell) 95: 1086-100. [CrossRef]

Fussell, Elizabeth, Sara R. Curran, Matthew D. Dunbar, Michael A. Babb, Luanne Thompson, and Jacqueline Meijer-Irons. 2017. Weather-Related Hazards and Population Change: A Study of Hurricanes and Tropical Storms in the United States, 1980-2012. Annals of the American Academy of Political and Social Science 669: 146-67. [CrossRef] [PubMed]

Gallagher, Justin, and Daniel Hartley. 2017. Household Finance after a Natural Disaster: The Case of Hurricane Katrina. American Economic Journal: Economic Policy 9: 199-228. [CrossRef]

Graif, Corina. 2016. (Un) Natural Disaster: Vulnerability, Long-Distance Displacement, and the Extended Geography of Neighborhood Distress and Attainment after Katrina. Population and Environment 37: 288-318. [CrossRef] [PubMed]

Hall, Sarah Marie. 2020. Revisiting Geographies of Social Reproduction: Everyday Life, the Endotic, and the Infra-Ordinary. Area 52: 812-19. [CrossRef]

Heglar, Mary Annaise. 2020. Home is Always Worth It. In All We Can Save: Truth, Courage, and Solutions for the Climate Crisis. Edited by A. E. Johnson and K. K. Wilkinson. New York: One World, pp. 279-86.

Hirata, Alexander J. 2015. Post Colonialism and the Marshallese Diaspora: Structural Violence and Health in the Marshallese Community in Springdale, Arkansas. Available online: https:/ / repository.usfca.edu/thes /170 (accessed on 3 September 2021).

Javeline, Debra. 2014. The Most Important Topic Political Scientists Are Not Studying: Adapting to Climate Change. Perspectives on Politics 12: 420-34. [CrossRef]

Kälin, Walter. 2008. Guiding Principles on Internal Displacement: Annotations. Washington, DC: The American Society of International Law. Available online: https:/ / www.brookings.edu/research/the-guiding-principles-on-internal-displacement-annotations2nd-edition (accessed on 7 September 2021).

Kälin, Walter. 2010. Conceptualising Climate-Induced Displacement. In Climate Change and Displacement: Multidisciplinary Perspectives. Edited by Jane McAdam. Oxford: Hart Pub.

Kohlatkur, Sheelah. 2019. The PG\&E Bankruptcy and the Coming Climate-Related Business Failures. The New Yorker, February 26. Available online: https:/ / www.newyorker.com/business/currency/the-pg-and-e-bankruptcy-and-the-coming-climate-relatedbusiness-failures (accessed on 28 June 2021).

Kromm, Chris, and Sue Sturgis. 2008. Hurricane Katrina and the Guiding Principles on Internal Displacement: A Global Human Rights Perspective on a National Disaster. Durham: Institute for Southern Studies.

LaCroix, Kevin. 2019. Securities Suit Arising from Climate-Caused Conditions Hits Utility. The DEO Diary, October 29. Available online: https: / /www.dandodiary.com/2019/10/articles/climate-change/securities-suit-arising-from-climate-change-causedconditions-hits-utility / (accessed on 28 June 2021).

Latour, Bruno. 2005. Reassembling the Social: An Introduction to Actor-Network Theory. Oxford: Oxford University Press.

Lea, Devin, and Sarah Pralle. 2021. To Appeal and Amend: Changes to Recently Updated Flood Insurance Rate Maps. Risk, Hazards E Crisis in Public Policy. [CrossRef]

Lees, Emma. 2017. Responsibility and Liability for Climate Loss and Damage after Paris. Climate Policy 17: 59-70. [CrossRef]

Long, Jason, and Henry E. Siu. 2016. Refugees from Dust and Shrinking Land: Tracking the Dust Bowl Migrants. Working Paper \#22108. Cambridge: National Bureau of Economic Research, Available online: https://www.nber.org/system/files/working_papers/w2 2108/w22108.pdf (accessed on 6 September 2021).

Mahajan, Parag, and Dean Yang. 2020. Taken by Storm: Hurricanes, Migrant Networks, and US Immigration. American Economic Journal: Applied Economics 12: 250-77. [CrossRef]

Marks-Block, T., F.K. Lake, R.B. Bird, and L.M. Curran. 2021. Revitalized Karuk and Yurok cultural burning to enhance California hazelnut for basketweaving in northwestern California, USA. Fire Ecology 17: 1-20.

Marshall, A.-M., and S. M. Sterett. 2019. Legal Mobilization and Climate Change: The Role of Law in Wicked Problems. Oñati Socio-Legal Series 9: 267-74. Available online: https:/ / opo.iisj.net/index.php/osls/article/view/1158 (accessed on 28 June 2021).

Martin, Isaac William. 2008. The Permanent Tax Revolt: How the Property Tax Transformed American Politics. Berkeley: University of California Press.

McAdam, Jane. 2010. Climate Change and Displacement: Multidisciplinary Perspectives. Oxford: Hart Pub.

Merry, Sally Engle. 2006. Human Rights and Gender Violence: Translating International Law into Local Justice. Chicago: University of Chicago Press.

Mount, Jeffrey, and Michael Dettinger. 2020. California's 21st Century Megadrought. Available online: https://www.ppic.org/blog/ californias-21st-century-megadrought/ (accessed on 28 June 2021).

Migration Policy Institute. Profile of the Unauthorized Population, Sonoma County, California. Available online: https://www. migrationpolicy.org/data/unauthorized-immigrant-population/county/6097 (accessed on 7 September 2021). 
National Research Council. 2010. National Security Implications of Climate Change for U.S. Naval Forces. Washington, DC: National Academies Press. Available online: http:/ / www.nap.edu/catalog.php?record_id=12897 (accessed on 7 September 2021).

National Research Council (U.S.). 2013. Climate and Social Stress: Implications for Security Analysis. Edited by John D. Steinbruner, Paul C. Stern and Jo L. Husbands. Washington, DC: National Research Council.

National Conference of State Legislatures (NCSL). 2021. States offering Drivers Licenses to Immigrants. Available online: https: / / www.ncsl.org/research/immigration/states-offering-driver-s-licenses-to-immigrants.aspx (accessed on 26 June 2021).

Norgren, J. 2004. The Cherokee Cases: Two Landmark Federal Decisions in the Fight for Sovereignty. Norman, Oklahoma: University of Oklahoma Press.

Ostrom, Elinor. 2009. A Polycentric Approach for Coping with Climate Change. World Bank Research Working Paper\#5095. Available online: https: / / papers.ssrn.com/sol3/papers.cfm?abstract_id=1494833\# (accessed on 7 September 2021).

Peel, J., H. Osofsky, and A. Foerster. 2019. A ‘Next Generation' of Climate Change Litigation?: An Australian Perspective. Oñati Socio-Legal Series 9: 275-307. Available online: https:/ /opo.iisj.net/index.php/osls/article/view/951 (accessed on 28 June 2021). [CrossRef]

Penn, I., L. Hepler, and P. Eavis. 2019. PG\&E Reaches $\$ 13.5$ Billion Deal With Wildfire Victims. The New York Times, December 6. Available online: https://www.nytimes.com/2019/12/06/business/energy-environment/pge-wildfire-victims-deal.html (accessed on 25 June 2021).

Pralle, Sarah. 2019. Drawing Lines: FEMA and the Politics of Mapping Flood Zones. Climatic Change 152: 227-37. [CrossRef]

Sawada, Yasuyuki, and Takasaki Yoshido. 2017. Natural Disaster, Poverty and Development: An Intro. World Development 94: 2-15. [CrossRef]

Simonelli, Andrea C. 2016. Governing Climate Induced Migration and Displacement: IGO Expansion and Global Policy Implications. New York: Palgrave Macmillan.

Smith, Dorothy. 1987. The Everyday World as Problematic: A Feminist Sociology. Boston: Northeastern University Press.

Sonoma County Department of Numbers. 2020. Sonoma County California Residential Rent and Rental Statistics. Available online: https:/ / www.deptofnumbers.com/rent/california/sonoma-county/ (accessed on 28 June 2021).

Stephens, Scott L., A. LeRoy Westerling, Matthew D. Hurteau, M. Zachariah Peery, Courtney A. Schultz, and Sally Thompson. 2020. Fire and Climate Change: Conserving Seasonally Dry Forests Is Still Possible. Frontiers in Ecology and the Environment 18: 354-60. [CrossRef]

Sterett, Susan M. 2015. Disaster, displacement, and casework: Uncertainty and assistance after Hurricane Katrina. Law E Policy 37: 61-92.

Sterett, Susan M., and Laura K. Mateczun. 2020. Displacement, legal mobilization, and disasters: Trial courts and legal process. Risk, Hazards \& Crisis in Public Policy 11: 348-76. [CrossRef]

Stokes, Leah C. 2018. Opinion: Climate Change in My Backyard. The New York Times, January 12. Available online: https://www. nytimes.com/2018/01/11/opinion/california-floods-mudslides-climate.html (accessed on 26 June 2021).

Strother, Logan. 2018. The National Flood Insurance Program: A Case Study in Policy Failure, Reform, and Retrenchment. Policy Studies Journal 46: 452-80. [CrossRef]

Sturgis, Sue. 2008. Institute Discusses Hurricane Katrina and Human Rights at Brookings. Facing South, January 15. Available online: https: / / www.facingsouth.org/2008/01/institute-discusses-hurricane-katrina-and-human-rights-at-brookings.html (accessed on 7 September 2021).

Theodoratus, Dorothea J. 1974. Cultural and Social Change Among the Coast Central Pomo. The Journal of California Anthropology 1: 206-19. Available online: https:/ / escholarship.org/uc/item/1gf3g3jx (accessed on 7 September 2021).

United States Census. n.d. Quick Facts: Sonoma County, California. Available online: https://www.census.gov/quickfacts/ sonomacountycalifornia (accessed on 28 June 2021).

United States Global Change Research Program (USGCRP). 2018. Impacts, Risks, and Adaptation in the United States: Fourth National Climate Assessment (NCA). Edited by D.R. Reidmiller, C. W. Avery, D. R. Easterling, K. E. Kunkel, K. L. M. Lewis, T. K. Maycock and B. C. Stewart. Washington, DC: U.S. Global Change Research Program, vol. II. [CrossRef]

U. S. Government Accountability Office (GAO). 2020. Climate Change: A Climate Migration Pilot Program Could Enhance the Nation's Resilience and Reduce Federal Fiscal Exposure. Available online: https: / www.gao.gov / products/gao-20-488 (accessed on 8 September 2021).

Vanhala, Lisa, and Cecilie Hestbaek. 2016. Framing Climate Change Loss and Damage in UNFCCC Negotiations. Global Environmental Politics 16: 111-29. [CrossRef] 